\title{
Bipartite talus
}

INSERM

\section{Source}

INSERM. (1999). Orphanet: an online rare disease and orphan drug data base. Bipartite talus. ORPHA:364198

Bipartite talus is a rare, genetic bone disorder characterized by the presence of two nonfused talar bone fragments, with the posterior fragment located at the level of the posterior talar process. Patients may present with foot and/or ankle pain (exerciseinduced or not), repetitive ankle sprains, chronic ankle lig amentous laxity, restricted ankle motion (i.e. plantar flexion, eversion, and inversion), and mild swelling. 